\title{
Acute pyelonephritis after recovery from heat stroke
}

\author{
Naomasa Yoshiyama (ㄷ) ${ }^{1}$ Hideaki Uzu, ${ }^{2}$ Takahiko Ito, ${ }^{2}$ Shinji Ogura ${ }^{3}$
}

${ }^{1}$ Department of Emergency

Medicine, Fukuoka-ken Saiseikai Futsukaichi Byoin, Chikushino, Fukuoka, Japan

${ }^{2}$ Department of Emergency Medicine, Omuta City General Hospital, Omuta, Fukuoka, Japan

${ }^{3}$ Department of Emergency and Disaster Medicine, Gifu University Hospital, Gifu, Gifu, Japan

\section{Correspondence to}

Dr Naomasa Yoshiyama; night_dreams_of_ophelia@ yahoo.co.jp

Accepted 17 June 2021
Check for updates

(C) BMJ Publishing Group Limited 2021. No commercial re-use. See rights and permissions. Published by BMJ.

To cite: Yoshiyama $\mathrm{N}$, Uzu H, Ito T, et al. BMJ Case Rep 2021;14:e244515. doi:10.1136/bcr-2021244515

\section{DESCRIPTION}

Heat stroke is a debilitating disease that is characterised by inflammation, coagulation and tissue abnormalities. ${ }^{1}$ Patients who have experienced heat stroke can manifest complications even after their body temperature has returned to normal. ${ }^{1}$ However, data on the characteristics of patients who developed complications after their recovery from heat stroke are scarce. Here, we present a case of an older adult who developed acute pyelonephritis with ureteral calculus after recovering from a heat stroke.

An 81-year-old man supposedly lost consciousness while working outside. He claimed to have undergone a surgery for oesophageal cancer 3 years ago. The patient's height and weight were $165 \mathrm{~cm}$ and $55 \mathrm{~kg}$, respectively. According to the patient's physical examination results, he had drowsiness, a Glasgow Coma Scale score of 14 (E3V5M6), a blood pressure of 200/110 $\mathrm{mm} \mathrm{Hg}$, a heart rate of 110 beats/min and a respiratory rate of 24 breaths/min. His body surface temperature was $40.1^{\circ} \mathrm{C}$ in the axillary region. Pain or infectious causes were not identified. Laboratory investigations revealed no findings suggestive of inflammation. An enhanced CT scan of the head, thorax, abdomen and pelvis showed a right urinary calculus with hydronephrosis and without perinephric fat stranding (figure 1). Consequently, the patient was diagnosed with heat stroke. Immediate body cooling using cold water and fluid infusion was performed. The patient's temperature decreased to $<38^{\circ} \mathrm{C}$ within $45 \mathrm{~min}$. He regained consciousness, and his vital signs were normalised. At 3 days after the onset of heat stroke, the patient developed fever and right flank pain. He was diagnosed with acute calculous pyelonephritis. Enterococcus faecalis was detected in blood and urinary culture findings. Accordingly, he received sulbactam/ampicillin (6 g/ day). Then, ureteral stenting was performed on day 4 of hospitalisation. The postoperative course was

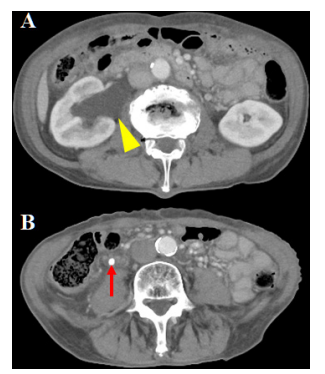

Figure 1 Enhanced CT reveals a hydronephrosis ((A) yellow triangle head) and right urinary calculous ((B) red arrow head). However, a perinephric fat stranding is not observed. unremarkable. Thus, the patient was discharged on day 10 of hospitalisation.

Intestinal bacteria enter the systemic circulation because of the increased gut permeability, which is caused by heat stroke. This results in endotoxemia, systemic inflammation and sepsis. ${ }^{12}$ In this case, the patient presented with acute calculous pyelonephritis with Enterococcus faecalis bacteraemia. The patient had an asymptomatic right urinary calculus with hydronephrosis before the onset of heat stroke. Enterococcus faecalis can travel from the gut to the systemic circulation via the urinary tract because of increased permeability of the vascular endothelium during heat stroke. Infectious urine remained in the right kidney with hydronephrosis and caused acute calculous pyelonephritis. The colonisation of Enterococcus faecalis may have also caused acute calculous pyelonephritis because of the retention of the urinary catheter for several days during the perioperative period of the patient following his oesophageal surgery 3 years ago. ${ }^{3}$ Immune suppression, which worsens during heat stroke, and the existence of urinary calculus could have led to the development of acute calculous pyelonephritis in this patient.

Patients with urinary calculus and hydronephrosis can develop acute pyelonephritis after recovering from heat stroke. Acute pyelonephritis should be

\section{Patient's perspective}

I was weeding the garden at home during the day, and I lost consciousness. The weather was ideal for weeding because it had been raining for a few days, although the day after was finally sunny. I had undergone a major surgery 3 years ago. I gradually recovered physically, although I became more sensitive to the cold. I wore three undershirts, a down jacket and a mask as a precaution against the coronavirus disease 2019. At 1 hour after starting work, I suddenly had difficulty moving; therefore, I called for an ambulance. I am fortunate to have recovered in a healthy state.

Learning points

Patients with urinary calculus and hydronephrosis can develop acute pyelonephritis after recovering from heat stroke.

- Acute pyelonephritis should be considered in patients with urinary calculus and hydronephrosis after recovering from a heat stroke, even if their physical examination findings are unremarkable. 
considered in patients with urinary calculus and hydronephrosis after recovering from a heat stroke, even if their physical examination findings are unremarkable. Further, a ureteral stent placement or percutaneous nephrostomy should be performed immediately after the recovery in such patients.

Acknowledgements The author would like to thank Mr Hisaji Kumagae, Hiroki Taura and Yoshihiro Kawaguchi for their technical support in treating the patient.

Contributors NY, HU and TI treated the patient. NY wrote the manuscript. SO supervised the report. All authors have read and approved the final manuscript.

Funding The authors have not declared a specific grant for this research from any funding agency in the public, commercial or not-for-profit sectors.
Competing interests None declared.

Patient consent for publication Obtained.

Provenance and peer review Not commissioned; externally peer reviewed.

\section{ORCID iD}

Naomasa Yoshiyama http://orcid.org/0000-0003-2002-7780

\section{REFERENCES}

1 Leon LR, Helwig BG. Heat stroke: role of the systemic inflammatory response. J App/ Physiol 2010;109:1980-8.

2 Lim C. Heat sepsis precedes heat toxicity in the pathophysiology of heat Stroke-A new paradigm on an ancient disease. Antioxidants 2018;7:149

3 Foxman B. The epidemiology of urinary tract infection. Nat Rev Urol 2010;7:653-60.

Copyright 2021 BMJ Publishing Group. All rights reserved. For permission to reuse any of this content visit

https://www.bmj.com/company/products-services/rights-and-licensing/permissions/

BMJ Case Report Fellows may re-use this article for personal use and teaching without any further permission.

Become a Fellow of BMJ Case Reports today and you can:

- Submit as many cases as you like

- Enjoy fast sympathetic peer review and rapid publication of accepted articles

- Access all the published articles

Re-use any of the published material for personal use and teaching without further permission

\section{Customer Service}

If you have any further queries about your subscription, please contact our customer services team on +44 (0) 2071111105 or via email at support@bmj.com.

Visit casereports.bmj.com for more articles like this and to become a Fellow 